\title{
METODE SOSIODRAMA BERPENGARUH TERHADAP MOTIVASI BELAJAR SISWA
}

\section{SOCIODRAMA METHOD EFFECT ON STUDENT LEARNING MOTIVATION}

\author{
F Agnia1a dan WRR Hayu ${ }^{1}$
}

\author{
1 Program Studi Pendidikan Guru Sekolah Dasar, Fakultas Keguruan dan Ilmu Pendidikan, \\ Universitas Djuanda Bogor, Jl. Tol Ciawi No. 1 Kotak Pos 35 Ciawi Bogor 16720 \\ a Korespondensi: Fibrina Agnia, Email: fibrinaagnia374@gmail.com \\ (Diterima: 17-11-2016; Ditelaah: 18-11-2016; Disetujui: 02-02-2017)
}

\begin{abstract}
This study was conducted to determine the influence of sociodrama method on improving students' learning motivation of third grade SDN 03 Klapanunggal to social sciences. Population and sample of this research was the third grade student of SDN 03 Klapanunggal consist of 70 students, 36 students for control class and 34 students for experimental class. The type of research used is Quasi Experimental Design. Based on the results of data analysis on statistical hypothesis test and independent $t$ test both showed the same significant value that is $0,00 \leq 0,05$ which means that the experimental class with the use of sociodrama method has influenced the social sciences learning motivation compared to the control class. The presence of a pleasant sociodrama method will influence students' learning motivation so it can improve student learning outcomes on social sciences. The learning motivation in the experimental class has been increased more than the control class.
\end{abstract}

Keyword: learning motivation, social sciences, sociodrama method.

\begin{abstract}
ABSTRAK
Penelitian ini dilakukan untuk mengetahui pengaruh metode sosiodrama terhadap peningkatan motivasi belajar siswa kelas III SDN 03 Klapanunggal pada mata pelajaran IPS. Populasi dan sampel penelitian ini adalah siswa kelas III SDN 03 Klapanunggal terdiri dari 70 siswa, 36 siswa untuk kelas kontrol dan 34 siswa untuk kelas eksperimen. Jenis penelitian yang digunakan adalah Quasi Experimental Design. Berdasarkan hasil analisis data pada uji hipotesis statistik dan independent $t$-test keduanya menunjukkan nilai signifikan yang sama yaitu $0,00 \leq 0,05$ yang berarti bahwa kelas eksperimen dengan penggunaan metode sosiodrama memberikan pengaruh terhadap motivasi belajar IPS dibandingkan dengan kelas kontrol. Adanya metode sosiodrama yang menyenangkan akan berpengaruh terhadap motivasi belajar siswa sehingga dapat meningkatkan hasil belajar siswa pada materi IPS. Motivasi belajar pada kelas eksperimen lebih meningkat dibandingkan dengan kelas kontrol. Kata kunci: IPS, metode sosiodrama, motivasi belajar.
\end{abstract}

Agnia F dan WRR Hayu. 2017. Metode sosiodrama berpengaruh terhadap motivasi belajar siswa. Didaktika Tauhidi Jurnal Pendidikan Guru Sekolah Dasar 4(1): 1-9.

\section{PENDAHULUAN}

Guru berperan dalam mengembangkan potensi siswa meliputi pembelajaran yang membuat siswa aktif, cerdas, dan berperilaku baik. Guru dituntut untuk kreatif dalam menggunakan berbagai metode, media, alat peraga maupun alat bantu sesuai dengan RPP (Rencana Perencanaan Pembelajaran). Karakter siswa 
yang bermacam-macam, menyebabkan metode yang monoton seperti penggunaan metode ceramah akan membuat siswa lebih mudah jenuh dan bosan, sehingga menjadikan mata pelajaran Ilmu Pengetahuan Sosial (IPS) pelajaran hafalan yang membosankan. IPS merupakan mata pelajaran yang memadukan disiplin ilmu sosial dan humaniora yang disajikan secara sistematis selaras dengan ilmu-ilmu sosial yang berada di dalamnya (Hartati 2016).

Motivasi belajar akan muncul ketika adanya stimulus yang dapat membuat anak merasakan rasa nyaman dan senang pada proses pembelajaran. Metode sosiodrama merupakan metode yang mudah untuk dipahami siswa kelas III yang digunakan dengan cara mengelompokkan beberapa siswa untuk memainkan sebuah peran dengan menggunakan sebuah naskah pada pembawaan materi membuat siswa aktif oleh perannya, memberanikan diri untuk memainkan peran di depan kelas, saling bekerja sama dengan temannya untuk memainkan peran dengan baik oleh siswa. Adanya metode ini juga membuat siswa mendalami peran mereka yang memfokuskan siswa pada materi yang dibawakan (Azizah 2015).

Menurut Bahri dan Zain (2013), guru membutuhkan metode yang bervariasi sesuai dengan jalan dan tujuan yang akan dicapai setelah waktu kegiatan belajar mengajar telah selesai. Dalam kegiatan belajar mengajar, guru bisa memberikan pengajaran yang menarik agar jalannya pengajaran tidak membosankan dan dapat menarik perhatian siswa.

Berdasarkan hasil observasi ditemukan beberapa permasalahan pada kelas III SDN 03 Klapanunggal khususnya pada materi IPS yaitu, metode yang kurang bervariasi dan monoton, nilai mata pelajaran IPS rendah, dan kurangnya motivasi dalam belajar sehingga siswa menjadi kurang aktif. Salah satu solusi bagi permasalahan tersebut yaitu dengan menggunakan metode sosiodrama. Dengan menggunakan metode ini, siswa diharapkan dapat memahami dan mengingat isi bahan yang akan didramakan, siswa akan terlatih untuk berinisiatif dan berkreatif, bakat yang terpendam pada siswa dapat dipupuk sehingga dimungkinkan akan muncul atau timbul bibit seni dari sekolah, kerjasama antara pemain dapat ditumbuhkan dan dibina dengan sebaik-baiknya, siswa memperoleh kebiasaan untuk menerima dan membagi tanggung jawab dengan sesamanya, serta bahasa lisan siswa dapat dibina menjadi bahasa yang baik agar mudah dipahami orang lain (Taniredja et al. 2013). Selain itu, munculnya karakteristik motivasi berupa dorongan untuk belajar secara aktif, pembelajaran yang efektif, semangat dan perilaku yang terarah, serta perubahan untuk mencapai tujuan, diharapkan dapat meningkatkan motivasi belajar siswa khususnya pada mata pelajaran IPS.

Metode sosiodrama dilakukan untuk meningkatkan motivasi siswa dalam belajar. Motivasi belajar penting bagi siswa dan guru. Bagi siswa pentingnya memotivasi siswa dapat dilakukan sebagai berikut: 1) menyadarkan kedudukan pada awal belajar, proses, dan hasil akhir; 2) mengarahkan kegiatan belajar; 3) membesarkan semangat belajar; 4) melewati tahapan belajar lalu bekerja (diselingi dengan waktu istirahat atau bermain) yang akan mempengaruhi jalannya individu untuk menjadi seseorang yang mau untuk maju dan berhasil (Dimyati dan Mudjiono 2013). Meningkatkan motivasi bisa dilakukan dengan menggunakan metode yang dapat merangsang rasa semangat siswa yang dapat berpengaruh terhadap hasil belajar, sehingga tujuan dari penelitian ini adalah 
untuk mengetahui adanya pengaruh metode sosiodrama terhadap motivasi belajar siswa kelas III pada mata pelajaran IPS.

\section{MATERI DAN METODE}

\section{Materi}

Pembelajaran merupakan hal yang penting untuk menumbuhkan ketertarikan siswa dengan cara memainkan peran atau drama. Hal tersebut adalah cara yang efektif dan efisien untuk meningkatkan motivasi belajar dan berpengaruh terhadap nilai mata pelajaran IPS yang masih rendah. Menurut Ruminiati dalam Azizah (2015), metode sosiodrama bertujuan untuk mempertunjukkan suatu perbuatan dari pesan yang ingin disampaikan dari peristiwa yang pernah dilihat. Metode ini juga menjadikan siswa menjadi senang, sedih, dan tertawa jika pemerannya dapat menjiwai dengan baik. Salah satu pesan dalam surat Al-Maidah ayat 27-31 menyiratkan sebuah sosiodrama dalam suatu alkisah permasalahan pada anak cucu Nabi Adam akibat sifat buruk yang memunculkan kedengkian, kejahatan, kedzaliman, untuk dijadikan sebuah pelajaran hidup dan motivasi diri untuk selalu berbuat baik dan tidak mudah mengikuti hawa nafsu dan tidak mengendalikan emosi pada diri sendiri.

Sriyono dalam Erawan (2014) berpendapat bahwa metode sosiodrama adalah suatu metode pembelajaran yang dilakukan dengan cara mendramatisasikan suatu tindakan atau tingkah laku dalam hubungan sosial. Dasar utama dari metode sosiodrama adalah drama. Beberapa individu akan terlibat permainan drama yang bertujuan untuk mempelajari dan memperbaiki masalah dalam hubungan sosial dalam kelompok (Ahyani dan Dhania 2011).

Pengajaran metode sosiodrama merupakan salah satu metode dengan memainkan peran yang menyenangkan seperti sandiwara atau dramatisasi tanpa bahan tertulis, tanpa latihan terlebih dahulu, dan tanpa menyuruh anak menghafal sesuatu. Cara pelaksanaan pembelajaran yang dilakukan oleh guru secara monolog dan hubungan satu arah. Aktivitas siswa dalam pembelajaran yang menggunakan metode ini hanya menyimak sambil sesekali mencatat.

\section{Metode}

\section{Lokasi}

Penelitian dilakukan di SDN 03 Klapanunggal yang beralamat di Kampung Tegal RT 25/07 Kembang Kuning, Cileungsi, Bogor.

\section{Jenis Penelitian}

Jenis Penelitian yang digunakan adalah Quasi Experimental Design. Kelas III SDN 03 Klapanunggal memiliki dua sampel pada kelas III yaitu kelas A dan B, sehingga desain yang dipilih adalah Non-equivalent control group design. Pada desain ini kelompok eksperimen maupun kelompok kontrol dipilih secara acak (random). Peneliti menggunakan desain penelitian menurut Sugiyono (2009) yang terdapat pada Gambar 1.

\begin{tabular}{|lll|}
\hline 01 & $X$ & 02 \\
\hline 03 & & 04 \\
\hline
\end{tabular}

Gambar 1 Desain penelitian

Keterangan: $01=$ kelompok sebelum diberi perlakuan; 02 = kelompok setelah diberi perlakuan; $\mathrm{X}=$ perlakuan metode sosiodrama; $03=$ kelompok sebelum diberi perlakuan; $04=$ kelompok tidak diberi perlakuan. 
Penelitian yang dilakukan menggunakan rancangan dua sampel dan dilakukan sebanyak dua kali. Dua sampel yang dimaksud adalah dua kelas sebagai sampel dari seluruh populasi. Sampel pertama merupakan kelompok eksperimen yang diberikan perlakuan menggunakan metode sosiodrama (bermain peran), yaitu latihan (drill). Sementara itu, sampel kedua adalah kelas yang tidak mendapat perlakuan pembelajaran dengan metode sosiodrama (bermain peran) atau kelompok kontrol.

\section{Populasi dan Sampel Penelitian}

Populasi adalah wilayah generalisasi terdiri atas objek atau subjek yang mempunyai kualitas dan karakteristik tertentu. Adapun sampel adalah sebagian dari jumlah dan karakteristik yang dimiliki oleh populasi tersebut. Populasi dan sampel dalam penelitian ini adalah sama yaitu siswa kelas III SDN 03 Klapanunggal yang berjumlah 70 siswa dan terbagi menjadi dua kelas, yaitu kelas III.A sebanyak 34 siswa untuk kelas eksperimen dan kelas III.B sebanyak 36 siswa untuk kelas kontrol. Teknik pengambilan sampling pada penelitian ini menggunakan sampling jenuh. Sampling jenuh adalah teknik penentuan sampel bila semua anggota populasi digunakan sebagai sampel (Sugiyono 2009).

\section{Variabel Penelitian}

Variabel bebas $(\mathrm{X})$ atau variabel independen dalam penelitian ini adalah metode sosiodrama (bermain peran) yang dilakukan pada kelompok eksperimen, sedangkan variabel terikat (Y) atau variabel dependen adalah motivasi belajar IPS. Selain itu, terdapat pula variabel kontrol antara lain waktu kegiatan belajar mengajar disamakan antara kelas kontrol dan eksperimen, guru yang mengajar untuk kelas kontrol dan eksperimen berbeda, dan materi disamakan antara kelas kontrol dengan kelas eksperimen.

\section{Teknik Pengumpulan Data}

Teknik pengumpulan data yang dilakukan dalam penelitian ini yaitu dengan cara: 1) mengumpulkan data sebelum perlakuan dengan memberikan pretest pada kelas kontrol dan eksperimen; 2) memberikan perlakuan pada kelas eksperimen; 3) mengumpulkan data setelah perlakuan dengan memberikan posttest pada kelas eksperimen; 4) mengumpulkan data posttest pada kelompok yang tidak diberikan perlakuan pada kelas kontrol; 5) observasi untuk keterlaksanaannya sosiodrama, observasi yang dilakukan melalui kegiatan belajar mengajar secara langsung, mengamati secara langsung respons dan ketertarikan siswa pada mata pelajaran IPS; dan 6) kuesioner (angket).

Angket akan dianalisis dengan menggunakan skala Likert sebagai pengukuran instrumen. Variabel yang akan diukur dijabarkan menjadi indikator variabel kemudian indikator tersebut dijadikan sebagai titik tolak untuk menyusun butir-butir instrumen yang dapat berupa pernyataan. Langkah-langkah dan jenis kegiatan belajar mengajar pada metode sosiodrama terdapat pada Tabel 1.

\section{Teknik Analisis Data}

Teknik analisis data yang digunakan dalam penelitian ini menggunakan uji validitas data untuk mengukur ketepatan instrumen yang digunakan dalam penelitian, menggunakan Bivariate correlation (Product Moment Pearson) dan Corrected item-total correlation. Untuk uji reliabilitas instrumen menggunakan rumus koefisien Cronbach's Alpha, dan angket dinyatakan reliabel apabila standar signifikannya $<0,7$ (Sugiyono 2009). Uji normalitas dilakukan 
pada nilai pretest dan posttest kelompok eksperimen dan kelompok kontrol. Uji yang digunakan adalah one-sample KolmogorovSmirnov test. Sementara itu, uji homogenitas dilakukan pada nilai pretest kelompok eksperimen dan kelompok kontrol. Statistik yang digunakan adalah Levene statistic.
Pengujian hipotesis dilakukan terhadap rata-rata nilai posttest kelompok eksperimen dan kelompok kontrol. Uji statistik yang digunakan ialah uji one sample t-test. Statistik uji yang digunakan untuk melihat pengaruh antara satu variabel independen dengan variabel dependen adalah one way ANOVA test.

Tabel 1 Langkah-langkah dan jenis kegiatan belajar mengajar metode sosiodrama

\begin{tabular}{|c|c|c|}
\hline No & Langkah-langkah & Jenis kegiatan belajar mengajar \\
\hline 1. & Persiapan & $\begin{array}{l}\text { - Menentukan dan menceritakan situasi sosial yang akan } \\
\text { didramatisasikan (metode ceramah) } \\
\text { - Memilih para pelaku } \\
\text { - Mempersiapkan pelaku untuk menentukan peranan masing- } \\
\text { masing }\end{array}$ \\
\hline 2. & Pelaksanaan & $\begin{array}{l}\text { - Siswa melakukan sosiodrama } \\
\text { - Guru menghentikan sosiodrama pada saat situasi sedang } \\
\text { memuncak (lupa dengan jalan ceritanya) maka dilanjutkan alur } \\
\text { ceritanya oleh guru. } \\
\text { - Akhiri sosiodrama dengan diskusi tentang jalan cerita, atau } \\
\text { pemecahan masalah selanjutnya. }\end{array}$ \\
\hline 3. & $\begin{array}{l}\text { Evaluasi atau } \\
\text { tindak lanjut }\end{array}$ & $\begin{array}{l}\text { - Siswa diberi tugas untuk menilai atau memberi. } \\
\text { - Siswa diberi kesempatan untuk membuat kesimpulan hasil } \\
\text { sosiodrama. }\end{array}$ \\
\hline
\end{tabular}

\section{HASIL DAN PEMBAHASAN}

\section{Hasil}

Data angket yang valid diperoleh setelah diujikan dengan SPSS 21.00 hanya 17 soal no $1,4,6,7,10,11,16,18,19,20,22,23,25$, $26,27,28,29,30$ karena standar nilai kevalidan adalah $\leq 0,05$ dan nilai reliabilitas 0,687 dengan standar raliabilitas $\geq 0,7$ maka angket dikatakan tidak reliable, lalu diujicoba kembali dengan membuang soal yang tidak valid namun hasilnya masih tidak reliable sebanyak 17 soal karena masih ada 2 soal yang tidak valid, dan hasilnya valid dan reliable dari ke 14 soal tersebut, namun angket tersebut masih belum memenuhi persyaratan karena masih ada satu indikator yang belum mewakili soal tersebut akhirnya peneliti menambahkan subjek di SDN Rawaragas lalu dijumlahkan dengan penelitian yang pertama ternyata hasilnya valid dan sangat reliable sebanyak 25 soal dan tidak valid 5 soal yaitu soal nomor 3, 4, 5, 6, 7. Berdasarkan hasil output yang diperoleh, ke-25 soal yang valid diujikan untuk angket yang digunakan sebagai penelitian di kelas III SDN 03 Klapanunggal.

\section{Uji Persyaratan Analisis Data}

Untuk mengetahui adanya pengaruh metode sosiodrama pada motivasi belajar maka 
dilakukan analisis data lanjut menggunakan uji normalitas dan uji homogenitas menggunakan pengukuran angket yang diujikan kepada siswa kelas III SDN 03 Klapanunggal melalui data pretest dan posttest.

\section{Uji Normalitas}

Uji normalitas digunakan untuk mengetahui apakah populasi data berdistribusi normal atau tidak. Jika nilai signifikan atau signifikasi atau probabilitas $\leq 0,05$ maka distribusi tidak normal. Sebaliknya distribusi normal jika nilai signifikansi atau nilai probabilitas $\geq 0,05$.

Tabel 2 Hasil uji normalitas

\begin{tabular}{|c|c|c|c|c|}
\hline \multirow{2}{*}{ Data } & \multicolumn{2}{|c|}{ Kelas Kontrol } & \multicolumn{2}{|c|}{$\begin{array}{c}\text { Kelas } \\
\text { Eksperimen }\end{array}$} \\
\hline & $\begin{array}{l}\text { Pre- } \\
\text { test }\end{array}$ & $\begin{array}{l}\text { Post- } \\
\text { test }\end{array}$ & $\begin{array}{l}\text { Pre- } \\
\text { test }\end{array}$ & $\begin{array}{l}\text { Post- } \\
\text { test }\end{array}$ \\
\hline Rata-rata & 79 & 80,47 & 87,6 & 91,29 \\
\hline $\begin{array}{l}\text { Nilai } \\
\text { tengah }\end{array}$ & 80,5 & 81,5 & 88,8 & 92 \\
\hline Variansi & 47,4 & 28,88 & 35,80 & 16,3 \\
\hline $\begin{array}{l}\text { Standar } \\
\text { deviasi }\end{array}$ & 6,89 & 5,3 & 5,98 & 4,04 \\
\hline $\begin{array}{l}\text { Skor } \\
\text { Minimum }\end{array}$ & 67 & 70 & 77 & 81 \\
\hline $\begin{array}{l}\text { Skor } \\
\text { Maksimum }\end{array}$ & 91 & 90 & 97 & 97 \\
\hline Signifikan & 0,14 & 0,2 & 0,2 & 0,12 \\
\hline
\end{tabular}

Berdasarkan hasil yang diperoleh untuk uji normalitas, hasil signifikan KolmogorovSmirnov kelas kontrol dan kelas eksperimen yang terdiri atas pretest dan posttest dapat dilihat pada Tabel 2. Pada tabel tersebut menunjukkan bahwa nilai signifikansi yang diperoleh untuk pretest kontrol 0,14 , pretest eksperimen 0,20, posttest kontrol 0,20 dan posttest eksperimen 0,13. Hal ini menunjukkan bahwa signifikan yang diperoleh dari normalitas $\geq 0,05$ yang berarti distribusi antara kelas kontrol dan eksperimen pada tahap pretest dan posttest bersifat normal.

\section{Uji Homogenitas}

Hasil uji homogenitas yang diperoleh dapat dilihat pada Tabel 3. Uji homogenitas dilakukan untuk mengetahui adanya varian yang sama dalam suatu kelas antara kelas kontrol dan kelas eksperimen. Berdasarkan data yang didapat melalui hasil angket pretest dan posttest motivasi belajar, signifikan pada homogenitas menunjukkan bahwa nilai 0,92 untuk kelas kontrol dan 0,66 untuk kelas eksperimen yang berarti nilai signifikan $\geq 0,05$ yang masuk pada kriterian varian kelas yang homogen atau sama.

Tabel 3 Hasil uji homogenitas

\begin{tabular}{cr}
\hline \multicolumn{3}{c}{ Signifikan ANOVA } \\
\hline Kontrol & 0,66
\end{tabular}

\section{Uji Hipotesis Statistik}

Setelah didapat hasil uji normalitas dan homogenitas pada kelas, tahap selanjutnya yaitu untuk melihat ada atau tidaknya pengaruh metode sosiodrama terhadap motivasi belajar pada kelas eksperimen dengan menggunakan uji hipotesis statistik. Berdasarkan hasil yang diperoleh, menunjukkan nilai signifikan sebesar 0,000 $\leq$ 0,05 (Tabel 4), yang berarti terdapat pengaruh pada penggunaan metode sosiodrama terhadap motivasi belajar. Hal ini juga dapat dilihat pada Tabel 2 yang menunjukkan nilai rata-rata kelas eksperimen lebih tinggi dibandingkan dengan kelas kontrol atau dengan kata lain antara kelas kontrol dan eksperimen terdapat pengaruh terhadap motivasi belajar siswa. 
Tabel 4 Hasil uji hipotesis statistik

\begin{tabular}{cc}
\hline Kelas Eksperimen & Kelas Kontrol \\
\hline Signifikan (2-tailed) 0,000
\end{tabular}

\section{Uji Independent $t$-test}

Adanya pengaruh antara kedua kelas maka tahap selanjutnya digunakan independent $t$ test untuk mengetahui perbedaan pengaruh antara kelas kontrol dengan kelas eksperimen. Berdasarkan uji yang dilakukan, maka diperoleh hasil signifikan $0,000 \leq 0,05$ menunjukkan bahwa kelas eksperimen dengan penggunaan metode sosiodrama memberikan pengaruh terhadap motivasi belajar IPS dibandingkan dengan kelas kontrol (Tabel 5).

Tabel 5 Hasil independent t-test

\begin{tabular}{lrr}
\hline Keterangan & \multicolumn{1}{c}{$\begin{array}{c}\text { Kelas } \\
\text { kontrol }\end{array}$} & \multicolumn{1}{c}{$\begin{array}{c}\text { Kelas } \\
\text { eksperimen }\end{array}$} \\
\hline Signifikan & 0,000 & 0,000 \\
Rata-rata & 80,47 & 91,29 \\
\hline
\end{tabular}

\section{Pembahasan}

Permasalahan-permasalahan

yang ditemukan pada SDN 03 Klapanunggal seperti metode yang kurang bervariasi, tidak adanya dorongan keinginan untuk berhasil, nilai mata pelajaran IPS rendah, dan kurangnya motivasi dalam belajar. Hal inilah yang melatarbelakangi peneliti untuk menguji adanya pengaruh metode sosiodrama untuk meningkatkan motivasi belajar.

Sebelum peneliti memberikan sebuah penelitian dengan menggunakan lembar kuesioner motivasi belajar, peneliti memberikan angket tersebut kepada Validator untuk divalidasi. Setelah redaksi dan pernyataan disetujui dan dikatakan baik oleh Validator maka lembar tersebut diujicoba ke sekolah lain untuk divalidasi agar dapat dijadikan angket penelitian di sekolah yang akan diteliti.

Hasil yang didapat pada uji validitas di Sekolah SDN 03 Klapanunggal bahwa jumlah soal angket yang valid adalah 17 soal, akan tetapi nilai signifikan reliabilitas yang diperoleh masih $\geq 0,7$ yaitu sebesar 0,68. Untuk itu peneliti mengujicoba kembali dengan drop soal yang tidak valid, namun hasil nilai signifikan dari uji coba yang kedua masih ada yang tidak valid. Akhirnya peneliti menambahkan subyek sebesar 12 siswa dari SDN Rawaragas dan diperoleh 25 soal valid, 5 soal drop dan signifikan dari reliabilitas senilai 0,97 atau sangat reliabel. Setelah peneliti mendapatkan lebih banyak jumlah soal yang valid pada uji coba yang terakhir dalam uji validitas maka peneliti menggunakan angket tersebut untuk diujicobakan sebagai angket penelitian di SDN 03 Klapanunggal.

Sebelum melaksanakan praktik, peneliti menyiapkan silabus dan RPP sebagai bahan pengajaran untuk melakukan praktik dalam memberikan perlakuan kepada siswa. Pada kelas kontrol dan kelas eksperimen diberikan soal pretest terlebih dahulu menggunakan soal yang sudah divalidasi oleh Validator, untuk mendapatkan perbandingan perubahan sebelum dan sesudah penelitian dilakukan. Penelitian dilakukan pada dua kelas, yaitu kelas kontrol diberikan metode ceramah seperti yang dilakukan pada kegiatan mengajar sehari-hari, dan kelas eksperimen.

Metode sosiodrama sangat menyenangkan untuk digunakan dalam sebuah pembelajaran karena seluruh siswa terlibat aktif untuk mengikuti pembelajaran dengan memainkan sebuah drama secara bergantian dengan kelompok lainnya maka timbulnya ketertarikan mereka terhadap suatu pembelajaran, dari mulai membaca naskah, berkelompok, menyiapkan peran 
mereka yang sudah dibagi-bagi adanya keinginan mereka untuk melihat temantemannya memainkan drama tersebut, akhirnya membuat siswa memahami cerita tersebut dan tidak hanya paham dengan sosiodramanya saja tapi juga materi yang sedang dibahas.

Setelah memberikan perlakuan metode sosiodrama terhadap siswa, lalu siswa diberi angket soal posttest. Berdasarkan hasil yang diperoleh pada uji normalitas signifikan pada pretest dan posttest $\geq 0,05$ yang berarti taraf signifikansi berdistribusi normal pada kedua kelas. Uji Hipotesis dilakukan untuk mengetahui adanya pengaruh perbedaan pada kedua kelas. Hasil uji menunjukkan signifikan pada kedua kelas sebesar 0,000 $\leq 0,05$ yang berarti kedua kelas tersebut sama-sama memiliki pengaruh. Terakhir peneliti menguji dengan menggunakan independent t-test, dari data yang didapat yaitu rata-rata untuk kelas kontrol dan kelas eksperimen menunjukkan bahwa pengaruh motivasi belajar pada kelas eksperimen lebih baik dibandingkan dengan kelas kontrol.

Hasil yang diperoleh sesuai dengan hasil penelitian yang dilakukan sebelumnya oleh Suarsana et al. (2013) mengenai pengaruh metode pembelajaran bermain peran berbantuan assesment kinerja terhadap hasil belajar IPS dan motivasi berprestasi kelas V SDN gugus II Laksamana Jembrana, lalu Rohmah dan Setyowati (2014) mengenai penggunaan metode sosiodrama menunjukkan peningkatan motivasi secara signifikan dan meningkatkan prestasi belajar siswa kelas VIII SMPN 2 Parang. Hal ini juga sesuai dengan Suprijono (2013) yang menyatakan bahwa motivasi adalah proses memberi semangat belajar, arah, dan kegigihan perilaku. Sedangkan metode sosiodrama pada dasarnya merupakan tingkah laku didramatisasikan yang berarti adanya proses serta pengaruh untuk meningkatkan motivasi belajar (Bahri dan Zain 2013). Metode sosiodrama dapat diterapkan untuk meningkatkan motivasi IPS yang dijelaskan oleh Ruminiati dalam Azizah (2015) yang menyatakan bahwa sosiodrama dapat membuat senang jika dimainkan dengan pengaturan pembelajaran yang benar, sehingga dapat meningkatkan motivasi belajar.

Berdasarkan hasil penelitian pada siswa kelas III di SDN 03 Klapanunggal menunjukkan adanya pengaruh motivasi belajar antara kelas yang tidak diberikan perlakuan dengan kelas yang diberikan perlakuan. Hal ini membuktikan bahwa metode sosiodrama dapat mempengaruhi motivasi belajar IPS siswa dan dengan adanya pembelajaran yang lebih menarik akan menimbulkan dampak positif bagi siswa.

\section{KESIMPULAN DAN IMPLIKASI}

\section{Kesimpulan}

Berdasarkan analisis data terdapat pengaruh metode sosiodrama terhadap motivasi belajar siswa kelas III SDN 03 Klapanunggal. Hal ini dilihat dari peningkatan nilai materi IPS pretest ke posttest pada kelas eksperimen dibandingkan dengan kelas kontrol. Adanya motivasi belajar dengan perlakuan metode sosiodrama merupakan salah satu cara yang dilakukan untuk mempengaruhi hasil belajar mata pelajaran IPS yang masih tergolong rendah di kelas III SDN 03 Klapanunggal.

\section{Implikasi}

Metode dalam sebuah pembelajaran sangat berpengaruh terhadap hasil belajar, dengan adanya metode sosiodrama yaitu suatu 
variasi dalam pembelajaran diharapkan dapat mempengaruhi motivasi belajar siswa pada materi IPS yang dirasa menjenuhkan oleh siswa kelas III SDN 03 Klapanunggal. Selain itu, guru juga diharapkan dapat memberikan pembelajaran dengan metode yang bervariasi dan tidak monoton karena dengan adanya metode pembelajaran yang menyenangkan akan berpengaruh terhadap motivasi belajar siswa yang dapat meningkatkan hasil belajar siswa.

\section{DAFTAR PUSTAKA}

Ahyani LN dan DR Dhania. 2011. Metode sosiodrama dalam meningkatkan kecerdasan moral anak. Jurnal Sosial dan Budaya. 4(2):143-149.

Azizah N. 2015. Peningkatan kualitas pembelajaran PKn melalui metode sosiodrama berbantu media boneka tangan pada siswa kelas IVA SDN Tambakaji 03 kota semarang. Skripsi. Program Studi Pendidikan Guru Sekolah Dasar Fakultas Ilmu Pendidikan Universitas Negeri Semarang, Semarang.

Bahri S dan A Zain. 2013. Strategi Belajar Mengajar. Rineka Cipta, Jakarta.

Dimyati dan Mudjiono. 2013. Belajar dan Pembelajaran. Rineka Cipta, Jakarta.

Erawan DGB. 2014. Penggunaan metode sosiodrama untuk meningkatkan kemampuan berwawancara dengan berbagai kalangan pada siswa kelas VIII SMP Mutiara Singaraja. Jurnal Santiaji Pendidikan. 4(1): 1-13.

Hartati Y. 2016. Evaluasi perencanaan pembelajaran ilmu pengetahuan sosial dengan pendekatan saintifik. Jurnal Sosial Humaniora. 7(1): 20-35.

Rohmah MA dan N Setyowati. 2014. Efektivitas pembelajaran melalui pengembangan metode sosiodrama dalam meningkatkan prestasi belajar PKn siswa kelas VIII SMPN 2 Parang. Jurnal Kajian Moral dan Kewarganegaraan. 2(2): 533-547.

Suarsana IBP, W Lasmawan, dan AAIN Marhaeni. 2013. Pengaruh metode pembelajaran bermain peran berbantuan asesmen kinerja terhadap hasil belajar IPS dan motivasi berprestasi kelas V SDN gugus II Laksamana Jembrana. e-Journal Program Pascasarjana Universitas Pendidikan Ganesha Jurusan Pendidikan Dasar. 3: 1-10.

Sugiyono. 2009. Metode penelitian kualitatif dan kuantitatif R\&D. Alfabeta, Bandung.

Suprijono A. 2013. Cooperative learning teori dan aplikasi PAIKEM. Pustaka Pelajar, Yogyakarta.

Taniredja T, ME Faridli, dan S Harmianto. 2013. Model-model pembelajaran inovatif dan efektif. Alfabeta, Bandung. 